\title{
Spectrophotometric Complexation Studies of Some Transition and Heavy Metals with a New Pyridine Derivative Ligand and Application of It for Solid Phase Extraction of Ultratrace Copper and Determination by Flame Atomic Absorption Spectrometry
}

\author{
Mahmood Payehghadr*, Kobra Shahbala, Homa Shafikhani \\ Department of Chemistry, Payame Noor University, Tehran, Iran \\ Email: ${ }^{*}$ mahmood_payehghadr@yahoo.com
}

Received October 7, 2012; revised November 9, 2012; accepted November 18, 2012

\begin{abstract}
A new pyridine derivative ligand, (E)-(Pyridine-2-ylmethylidene) (\{2-(E)-(Pyridine-2-ylmethylidene) amino] ethyl $\}$ has been synthesized and $\mathrm{k}_{\mathrm{f}}$ value of it's complexes with $\mathrm{Cu}^{2+}, \mathrm{Ni}^{2+}, \mathrm{Cd}^{2+}, \mathrm{Zn}^{2+}, \mathrm{Co}^{2+}, \mathrm{Hg}^{2+}$ and $\mathrm{Ag}^{+}$has been determined spectrophometrically. The stability of the complexes to vary in acetonitrile solvent was in the order of $\mathrm{Cu}^{2+}>\mathrm{Ni}^{2+}>$ $\mathrm{Cd}^{2+}>\mathrm{Zn}^{2+}>\mathrm{Co}^{2+}>\mathrm{Hg}^{2+}>\mathrm{Ag}^{+}$, thus because this ligand have good selectivity to copper ion, a simple, reliable and rapid method for preconcentration and determination of the ultratrace amount of copper using octadecyl silica membrane disk modified by this ligand, and determination by flame atomic absorption has been presented. Various parameters including $\mathrm{pH}$ of aqueous solution, flow rates, the amount of ligand and the type of stripping reagent were optimized. Under optimum experimental conditions, the breakthrough volume is greater than $2000 \mathrm{ml}$ with an enrichment factor of more than 400 and $0.054 \mu \mathrm{g} \cdot \mathrm{L}^{-1}$ detection limit. The capacity of the membrane disks modified by $6 \mathrm{mg}$ of the ligand has been found to be $330.17 \mathrm{~g}$ of copper. The effects of various cationic interferences on the percent recovery of copper ion were studied. The method has been successfully applied for the determination of copper ion in different water samples.
\end{abstract}

Keywords: Copper; SPE; C18; Oyridine; FAAS; Spectrophotometry; Formation Constant

\section{Introduction}

The coordination chemistry of pyridine, bipyridine (bipy), terpyridine (terpy), phenantroline (phen), naphthyridine (naphthy) and pyridine-pyridazine (pyridaz) have received more and more attention since the late 19th century [1-3]. Coordination chemistry of these ligands with different metal to ligand ratio results in different geometries, such as tetrahedral [4], squar plannar, pentagonal bipyramidal [5], or octahedral [6,7]. These organic ligands containing unsaturated nitrogen atoms can be regarded as soft Lewis bases [8].

As such compounds may reveal high tendency for stable coordination complexes with numerous transition metal ions, particularly those that can be regarded as soft Lewis acids such as $\mathrm{Cu} 1$ ) and $\mathrm{Cu} 2$ ). The polyimine ligands (Figure 1) were chosen as suitable building blocks for these complexation reaction. These compounds are flexibile about the central C-C bond. Each of these ligands contains four potential sites for coordina-

* Corresponding author. tion to metal ions, the peripheral pyridyl- $\mathrm{N}$ as well as the inner imino $\mathrm{N}$-atoms. In this work we focus on a series of new 2,2'-bipyridyle-type organic ligands with added matal coordination functionality along the molecular backbone. The complexation process has been monitored by UV/Vis absorption spectroscopy.

Among the chemical species copper has a biological action at low doses and a toxic effect when ingested in larger quantities. A concentration more than $1 \mu \mathrm{g} \cdot \mathrm{mL}^{-1}$ of copper can impart a bitter taste to water. Large oral doses can cause vomiting and may eventually cause liver damage. Copper concentration in potable water is usually very low $\left(20 \mu \mathrm{g} \cdot \mathrm{L}^{-1}\right)$ [9]. Determination of copper isusually carried out by flame [10-12] and graphite [13,14] atomic absorption spectrometry, as well as spectrophotometry

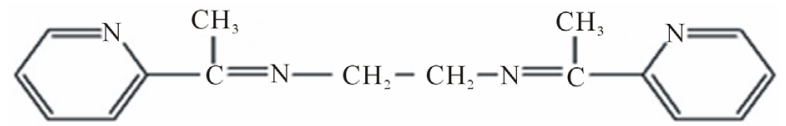

Figure 1. Chemical structure of BPYMH. 
[15,16], chemiluminescence [17] and electrothermal methods $[18,19]$. However, due to presence of copper in low levels in environmental samples and the matrix effects, different separation and preconcentration techniques such as liquid-liquid extraction [20], precipitation [21], ion exchange [22], solid phase extraction [23,24] and membrane filtration [25] improve the analytical detection limit, increase the sensitivity by several orders of magnitude, enhance the accuracy of the results and facilitate the calibration. Among these techniques, solid phase extraction is preferred by many researchers on account of the fast, simple and higher preconcentration factor, rapid phase separation, time and cost saving [26,27]. A number of supports have been widely used for the preconcentration and separation of trace metal ions from various matrices. Among the absorbents, silica with chemically bonded alkyl chains such as octadecyl bonded silica (C18), modified by suitable ligands has been an excellent used extractor of metal ions [28-32]. In this work a newly synthesized ligand, ((E)-(Pyridine-2-ylmethylidene) (\{2-(E)-(Pyridine-2-ylmethylidene) amino] ethyl $\}$ ) (BPYMH) (Figure 1), is studied as a disk modifier for $\mathrm{Cu} 2$ ) ion. Also, we report on extraction and preconcentration of copper 2) from water samples and determination by atomic absorption spectrometry.

\section{Experimental}

\subsection{Instruments}

All UV-Vis Spectra recorded on a computerized double-beam 2550 Shimadzu spectrophotometer, using two matched $10 \mathrm{~mm}$ quartz cell. In a typical experiment, 2.0 $\mathrm{ml}$ of ligand solution $\left(5.0 \times 10^{-5} \mathrm{~mol} \cdot \mathrm{L}^{-1}\right)$ in acetonitrile was placed in the spectrophotometer cell and the absorbance of solution was measured. Then a known amount of the concentrated solution of metal ions in acetonitrile $\left(1.3 \times 10^{-3} \mathrm{~mol} \cdot \mathrm{L}^{-1}\right)$ was added in a stepwise manner using an $10 \mu$ l Hamilton syringe. The absorbance of the solution was measured after each addition. The metallic ions solution was continually added until the desired metal to ligand mole ratio was achieved.

The determinations of copper were performed on a GBC Sens AA flame atomic absorption spectrometer (air-acetylene flame) with Hollow Cathode Lamp (HCL) and equipped with a deuterium background corrector. The absorbance wavelength was set at $324.7 \mathrm{~nm}$ and the spectral bandwidth at $0.5 \mathrm{~nm}$. A Metrohm $827 \mathrm{pH}$ meter was used to measure $\mathrm{pH}$ values.

The modified $\mathrm{C} 18$ extraction disks were used in conjunction with a standard $47 \mathrm{~mm}$ filtration apparatus (Schleicher and Schüell, Dassel, Germany) connected to a vacuum.

\subsection{Chemicals}

Methanol, acetonitrile and other organic solvents were used spectroscopic grade from Merck. All mineral acids were of pro analysis from Merck. Analytical grade standard stock of copper 2), sodium hydroxide and nitrate or chloride salts of magnesium, zinc, cobalt, manganese, lead, nickel, cadmium, silver, mercury, sodium, potassium and calcium (all from Merck) were of the highest purity available. The new synthesized BPYMH ligand with the highest purity was used as a chelating ligand. Working standards were prepared by appropriate dilution of the stock solution with deionized water.

\subsection{Estimation of Formation Constants}

The formation constant $(\mathrm{kf})$ and the molar absorptivity $(\varepsilon)$ of the resulting 1:1 complexes between the BPYMH ligand and different metallic ions in acetonitrile at $25^{\circ} \mathrm{C}$ were calculated by fitting the observed absorbance, Aobs, at various metallic ion/ligand mole ratios to the previously derived equations [33,34] (Equation (1)), which express the Aobs as a function of the free and complexed metal ions and the formation constant evaluated from a non-linear least-squares program KINFIT [35].

\subsection{Sample Extraction}

Extraction were performed with a $47 \mathrm{~mm}$ diameter $\times 0.5$ $\mathrm{mm}$ thickness, Empore high performance extraction membrane disk containing octadecyl-bonded silica $(8 \mu \mathrm{m}$ particles, $6 \mathrm{~nm}$ pore size) from $3 \mathrm{M}$ company. The disks were used in conjunction with a standard Scott Duran 47 $\mathrm{mm}$ filtration apparatus.

After placing the membrane in the filtration apparatus, it was washed with $10 \mathrm{ml}$ methanol and then with $10 \mathrm{ml}$ deionized water to remove all contaminations arising from the manufacturing process and the environment. After drying the disk by passing air through it for several minutes, a solution of $6 \mathrm{mg}$ BPYMH ligand dissolved in $3 \mathrm{ml}$ acetonitrile was introduced to the reservoir of the apparatus and was drawn slowly through the disk by applying a slight vacuum. The filtration step was repeated until the passed solution was completely clear. Finally, the disk was washed with $25 \mathrm{ml}$ deionized water and dried by passing the air through it. The membrane disk modified by the BPYMH ligand was then ready for sample extraction. It is important to note that the surface of the disk was not left to become dry from the methanol was added until the extraction of $\mathrm{Cu}^{2+}$ ions from water were completed [36].

Then $100 \mathrm{ml}$ of the sample solution containing $10 \mu \mathrm{g}$ $\mathrm{Cu}^{2+}$ was passed through the membrane (flow rate $=5$ $\mathrm{ml} / \mathrm{min}$ ). After the extraction, the disk was dried completely by passing air through it for a few minutes. The extracted copper was stripped from the membrane disk using appropriate amounts of suitable eluent (the best eluent was $1 \mathrm{M}$ nitric acid). This step was done with $5 \mathrm{ml}$ eluent solution and the $\mathrm{Cu}^{2+}$ was determined with flame 
atomic absorption spectrometer.

\section{Result and Discussion}

\subsection{Spectrophotometric Studies}

Spectrophotometric studies of complexation reaction between the BPYMH ligand and metallic ions in acetonitrile solution revealed that ligand can form stable 1:1 (metallic ion to ligand) complexes with different metallic ions.

The electronic absorption spectra of BPYMH ligand (5 $\left.\times 10^{-5} \mathrm{~mol} \cdot \mathrm{L}^{-1}\right)$ in the presence and increasing con centration of $\mathrm{Cu}^{2+}\left(1.3 \times 10^{-3} \mathrm{M}\right)$ ions were recorded (Figure 2) in acetonitrile at $25^{\circ} \mathrm{C}$. The resulting complexe of $\mathrm{Cu}^{2+}$ with BPYMH ligand are distinguished by a little spectral shift toward longer wavelength.

The stoichiometry of the metal complexes was examined by the mole ratio method. Sample of the resulting plots for all $\mathrm{Mn}^{+}-\mathrm{L}$ complexes are shown in Figure 3, at $297 \mathrm{~nm}$, and it is evident that 1:1 (metallic ion to ligand) complexes are formed in solution. The formation constants of the resulting 1:1 metallic ions to the BPYMH complexes were obtained at $25^{\circ} \mathrm{C}$ by absorbance measurements of solutions in which varying concentrations of metallic ions were added to fixed amounts $\left(5.0 \times 10^{-5}\right.$ $\left.\mathrm{mol} \cdot \mathrm{L}^{-1}\right)$ of ligand solution. All the resulting absorbance-mole ratio data were best fitted to Equation (1), which further supports the formation of ML in solution.

$$
K_{f}[L]^{2}+\left(1+K_{f} C_{M}-K_{f} C_{L}\right)[L]-C_{L}=0
$$

For evaluation of the formation constants and molar absorptivity coefficients from absorbance vs. [M]/[L] mole ratio data, a non-linear least squares curve fitting program KINFIT was used. A sample computer fit of the absorbance-mole ratio data is shown in Figure 4. All of the $\log K_{f}$ values evaluated from the computer fitting of the corresponding absorbance-mole ratio data at $25^{\circ} \mathrm{C}$ are

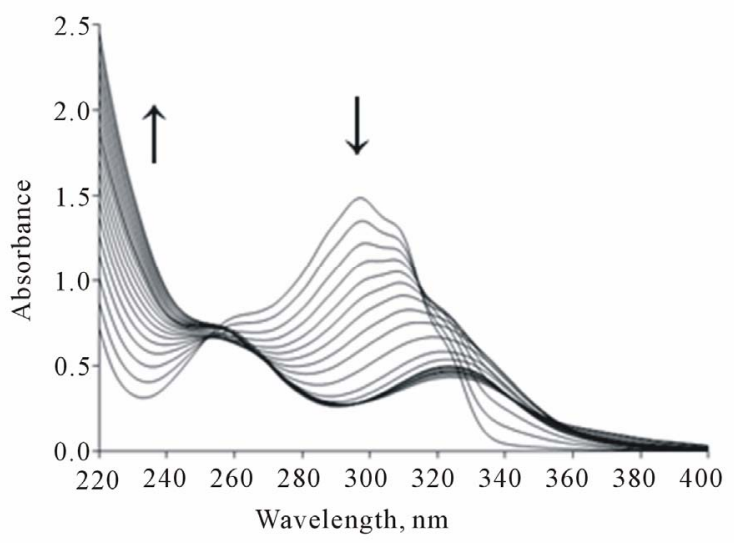

Figure 2. The spectrum of ligand solution $\left(5.00 \times 10^{-5} \mathrm{M}\right)$ in acetonitrile and increasing concentration of $\mathrm{Cu}^{2+}$ ion solution $\left(1.30 \times 10^{-3} \mathrm{M}\right)$. listed in Table 1. The data given in Table 1 revealed that, at $25^{\circ} \mathrm{C}$, the stabilities of the complexes varies in the or$\operatorname{der} \mathrm{Cu}^{2+}>\mathrm{Ni}^{2+}>\mathrm{Cd}^{2+}>\mathrm{Zn}^{2+}>\mathrm{Co}^{2+}>\mathrm{Hg}^{2+}>\mathrm{Ag}^{+}$.

Thus, considering the observed stability, we decided to use ligand as a suitable modifier for the selective concentration and extraction of $\mathrm{Cu}^{2+}$ ions on the octadecyl silica membrane disks. Some preliminary experiments were undertaken in order to investigate ligand retention of copper ions by the membrane disk in the presence of ligand, after the recommended washing, wetting and conditioning procedures were carried out. It was found that, the membrane disk modified by the BPYMH ligand is capable to retain $\mathrm{Cu}^{2+}$ ions in the sample solution quantitatively (the test solution used contained $10 \mu \mathrm{g}$ copper in $100 \mathrm{ml}$ water at $\mathrm{pH} 7.0$ ).

\subsection{Solid Phase Extraction}

\subsubsection{Choice of Eluent}

In order to choose the most effective eluent for quantitative stripping of retained ions from the modified diskafter extraction of $10 \mu \mathrm{g} \mathrm{Cu}^{2+}$ from $100 \mathrm{ml}$ sample (in the presence of $6 \mathrm{mg}$ ligand), the ions were stripped with 5 $\mathrm{ml}$ of different inorganic solution and the resulting data are listed in Table 2.

From the data given in Table 2, it is immediately obvious

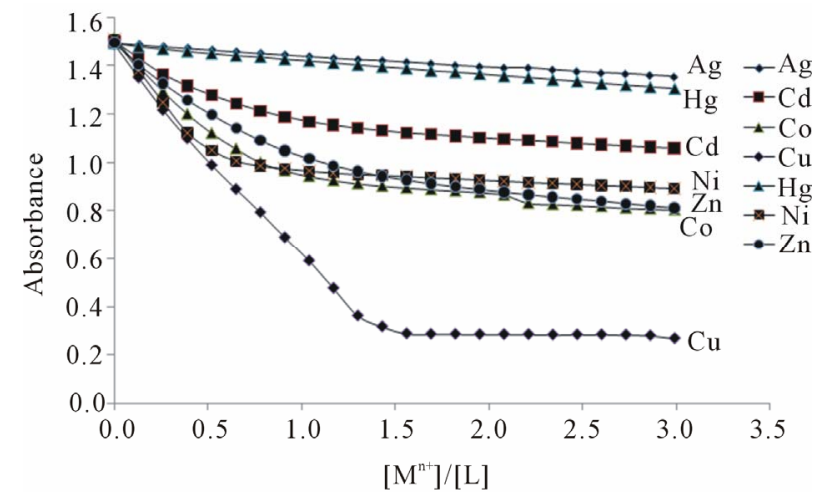

Figure 3. Mole ratio plots of absorbance as $\left[\mathrm{M}^{\mathrm{n}+}\right] /[\mathrm{L}]$ at 297.

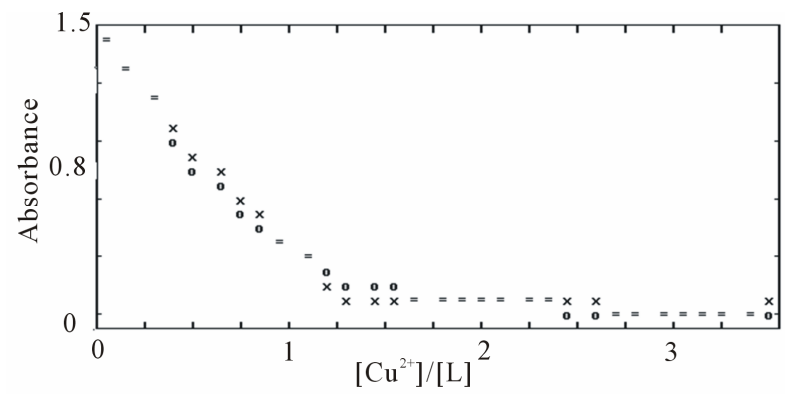

Figure 4. Computer fit of absorbance versus $\left[\mathrm{Cu}^{2+}\right] /[\mathrm{L}]$ mole ratio plot in acetonitrile at $25^{\circ} \mathrm{C},(\times)$ experimental point, $(O)$ calculated point, $(=)$ experimental and calculated points are the same within the resolution of the plot. 
that among the different solutions, $5 \mathrm{ml} 1 \mathrm{M}$ nitric acid can a accomplish the quantitative elution of copper from the membrane disk, while other solutions are ineffective for the complete elution of copper.

\subsubsection{Effect of Ligand Amount}

The optimum amount of the ligand for the membrane disks was studied. The results of the amount of ligand play an important role in obtaining quantitative recoveries of metal ions, because in its absence, the disk does not retain the metal ions. Therefore, the influence of the amount of ligand on recovery of the copper ion was examined in the range of $5-15 \mathrm{mg}$ using $100 \mathrm{ml}$ solution

Table 1. Formation constants of different ligand- $\mathrm{M}^{\mathrm{n}+}$ complexes.

\begin{tabular}{cc}
\hline Metallic ion & $K_{f} \pm \mathrm{SD}$ \\
\hline $\mathrm{Cu}^{2+}$ & $5.24 \pm 0.02$ \\
$\mathrm{Ni}^{2+}$ & $4.98 \pm 0.01$ \\
$\mathrm{Cd}^{2+}$ & $4.75 \pm 0.01$ \\
$\mathrm{Zn}^{2+}$ & $4.56 \pm 0.01$ \\
$\mathrm{Co}^{2+}$ & $3.91 \pm 0.01$ \\
$\mathrm{Hg}^{2+}$ & $2.95 \pm 0.02$ \\
$\mathrm{Ag}^{+}$ & $1.44 \pm 0.02$ \\
\hline
\end{tabular}

Table 2. Percent recovery of copper from the modified membrane disk using $5 \mathrm{ml}$ of different stripping solutions.

\begin{tabular}{|c|c|}
\hline Stripping solution and it's concentration & $\%$ Recovery \\
\hline $\mathrm{HCl}(0.05 \mathrm{M})$ & 49.5 \\
\hline $\mathrm{HCl}(0.10 \mathrm{M})$ & 76.5 \\
\hline $\mathrm{HCl}(0.50 \mathrm{M})$ & 78.5 \\
\hline $\mathrm{HCl}(1.00 \mathrm{M})$ & 82.0 \\
\hline $\mathrm{HNO}_{3}(0.05 \mathrm{M})$ & 84.5 \\
\hline $\mathrm{HNO}_{3}(0.10 \mathrm{M})$ & 96.5 \\
\hline $\mathrm{HNO}_{3}(0.50 \mathrm{M})$ & 98.5 \\
\hline $\mathrm{HNO}_{3}(1.00 \mathrm{M})$ & 99.6 \\
\hline $\mathrm{H}_{2} \mathrm{SO}_{4}(0.05 \mathrm{M})$ & 41.5 \\
\hline $\mathrm{H}_{2} \mathrm{SO}_{4}(0.10 \mathrm{M})$ & 55.0 \\
\hline $\mathrm{H}_{2} \mathrm{SO}_{4}(0.50 \mathrm{M})$ & 72.0 \\
\hline $\mathrm{H}_{2} \mathrm{SO}_{4}(1.00 \mathrm{M})$ & 54.0 \\
\hline $\operatorname{EDTA}(0.05 \mathrm{M})$ & 50.5 \\
\hline $\operatorname{EDTA}(0.10 \mathrm{M})$ & 61.0 \\
\hline EDTA $(0.50 \mathrm{M})$ & 74.0 \\
\hline
\end{tabular}

containing $10 \mu \mathrm{g}$ copper ions. The recoveries of copper ion reached to $100 \%$ with $6 \mathrm{mg}$ of ligand (Figure 5). On this basis, in all studies were carried out with $6 \mathrm{mg}$ of BPYMH ligand.

\subsubsection{Effect of Flow Rate and pH}

The effect of flow rates of the sample and stripping solutions from the modified membrane disk on the retention and recovery of copper ion was investigated. It was found that, in the range of $5.0-20 \mathrm{ml} \cdot \mathrm{min}^{-1}$, the retention of copper by the membrane disk is not affected by the sample solution flow rate considerably. Similar results for extraction metal ions have already been reported [37]. In this work quantitative stripping of copper ion from the disk was achieved in a flow rate of $2.0-5 \mathrm{ml} \cdot \mathrm{min}^{-1}$, using $5 \mathrm{ml}$ of $1 \mathrm{M}$ Nitric acid.

Most chelating ligands are conjugate bases of weak acid groups and accordingly, have a very strong affinity for hydrogen ions. The $\mathrm{pH}$ therefore, will be a very important factor in the separation of metal ions by chelating, because it will determine the values of the conditional stability constants of the metal complexes on the surface of the sorbent [38]. In order to investigate the effect of $\mathrm{pH}$ on the SPE of copper ion, the $\mathrm{pH}$ of aqueous samples was varied from 2 - 9, using different buffers, and the recommended procedure was followed. As shown in Figure 6 the $\mathrm{Cu}^{2+}$ ion can be retained quantitatively in the $\mathrm{pH}$ range of $7.0-8.0$. For subsequent experiments, $\mathrm{pH}=7$ was chosen as a working $\mathrm{pH}$. Higher $\mathrm{pH}$ values $(>9)$ were not tested because of the possibility of the hydrolysis of octadecyl silica in the disks.

\subsubsection{Analytical Performance}

\subsubsection{Sorption Capacity}

The maximum capacity of the disk was determined by passing $50 \mathrm{ml}$ portions of an aqueous solution containing $500 \mu \mathrm{g}$ copper ion, through the modified disk with BPYMH ligand, followed by determination of the retained ions using FAAS. The maximum capacity of the disk was found to be $330.2( \pm 8.1) \mu \mathrm{g}$ copper ion per $6 \mathrm{mg}$ of ligand.

\subsubsection{Breakthrough Volume}

Since Breakthrough volume represents the sample volume that can be pre-concentrated without the loss of analyte during elution of the sample, the measurement of breakthrough volume is important in solid phase extraction. The breakthrough volume of the sample solution was tested by dissolving $10 \mu \mathrm{g}$ of copper ion in 50,100, 250, 500, 1000 and $2000 \mathrm{ml}$ water and the recommended procedure was followed. In all cases, the extraction by modified disks was found to be quantitative. Thus, the breakthrough volume for the method should be greater than $2000 \mathrm{ml}$. Consequently, by considering the final 


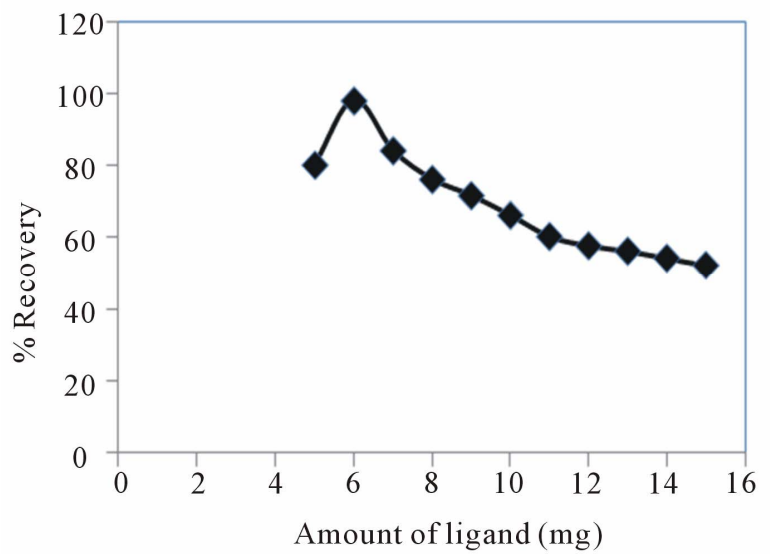

Figure 5. Effect of ligand amount on extraction recovery of copper ion.

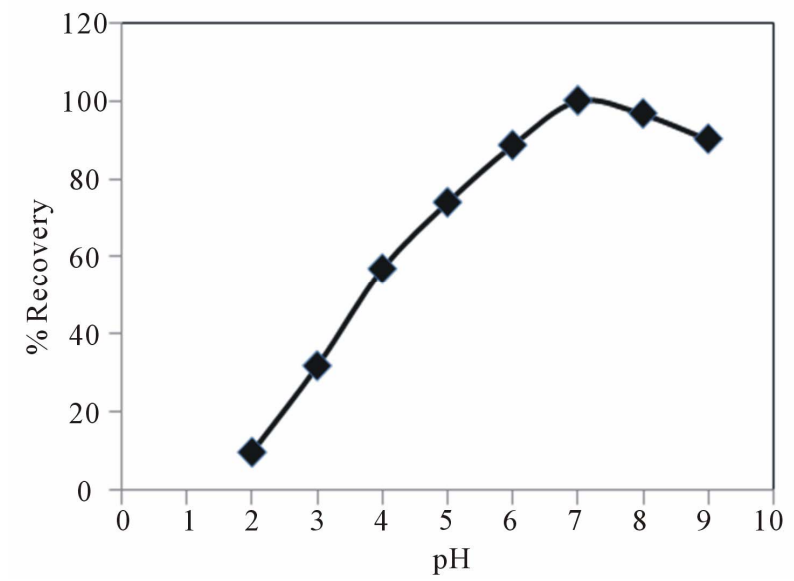

Figure 6. Effect of pH on copper(II) extraction. Copper(II) $=10 \mu \mathrm{g}$, aqueous phase volume $=100 \mathrm{ml}$.

elution volume of $5 \mathrm{ml}$ and the sample solution volume of $2000 \mathrm{ml}$, an enrichment factor of around 400 was easily available.

\subsubsection{Limit of Detection}

The limit of detection (LOD), of the proposed method for the determination of copper ion was studied under the optimal experimental conditions. The LOD obtained from CLOD $=K_{b} S_{b} \mathrm{~m}^{-1}$ for a numerical factor $K_{b}=3$ is $0.054 \mu \mathrm{g}$ per $1000 \mathrm{ml}$.

\subsubsection{Effect of Diverse Ions on Sorption of Copper}

In order to investigate the selective separation and determination of $\mathrm{Cu}^{2+}$ ion from its binary mixtures with divers metal ions, a $100 \mathrm{ml}$ aliquot solution containing 10 $\mu \mathrm{g} \mathrm{Cu}^{2+}$ and milligram amounts of other cations was taken and the recommended procedure was followed. The results are summarized in Table 3. The results show that the copper ions in the binary mixtures are retained almost completely by the modified membrane disk.
3.2.4.5. Analysis of Artificial and Natural Water Samples To test the applicability of the developed procedure, it was applied to the extraction and determination of copper ions from some water samples. Tap water of Abhar and Zanjan cities, two fountains in Tarom city and synthetic water samples were analyzed. The results for this study are presented in Table 4. The recovery of samples is satisfactory reasonable and was confirmed using addition method, which indicates the capability of the system in determination of ions. A good agreement was obtained between the added standards and measured analyte amounts. The recovery values calculated for the added standards were always higher than $90 \%$, thus confirming the accuracy of the procedure and its independence from the matrix effects.

Table 3. Effect of divers ions on the recovery of $10 \mu \mathrm{g}$ copper ion ${ }^{1}$.

\begin{tabular}{ccc}
\hline $\begin{array}{c}\text { \% Copper } \\
\text { recovery }\end{array}$ & $\begin{array}{c}\text { Amount taken, } \\
\mathrm{mg}\end{array}$ & Diverse ions \\
\hline 98.3 & 100 & $\mathrm{Na}^{+}$ \\
98.8 & 100 & $\mathrm{~K}^{+}$ \\
Precipitated & 20 & $\mathrm{Ca}^{2+}$ \\
99.6 & 20 & $\mathrm{Mg}^{2+}$ \\
97.2 & 1 & $\mathrm{Ni}^{2+}$ \\
99.8 & 1 & $\mathrm{Co}^{2+}$ \\
96.4 & 1 & $\mathrm{Zn}^{2+}$ \\
98.6 & 1 & $\mathrm{Mn}^{2+}$ \\
Precipitated & 1.5 & $\mathrm{~Pb}^{2+}$ \\
98.5 & 20 & $\mathrm{Na}^{+}, \mathrm{K}^{+}, \mathrm{Mg}^{2+}$ \\
99.1 & 0.5 & $\mathrm{Ni}^{2+}, \mathrm{Co}^{2+}, \mathrm{Zn}^{2+}$ \\
\hline
\end{tabular}

${ }^{1}$ Initial samples contained $10 \mu \mathrm{g} \mathrm{Cu}{ }^{2+}$ and different amounts of various ions in $100 \mathrm{ml}$ water.

Table 4. Determination of copper ions in real water samples. Aqueous phase. $100 \mathrm{ml}$ sample solution $\mathrm{pH}=7$ (with $0.01 \mathrm{M}$ of phosphate buffer), amount of ligand $=6 \mathrm{mg}$, eluent $=5$ $\mathrm{ml}\left(1 \mathrm{M} \mathrm{HNO}_{3}\right)$.

\begin{tabular}{ccc}
\hline Copper recovery $\left(\mu \mathrm{g} \cdot \mathrm{L}^{-1}\right)$ & $\mathrm{Cu}^{2+}$ added $(\mu \mathrm{g})$ & Water samples \\
\hline 30.6 & 0 & Fountain water 1 \\
41.2 & 10 & \\
61.2 & 0 & Fountain water 2 \\
70.8 & 10 & \\
260.8 & 0 & Tap water of Zanjan \\
272.8 & 10 & \\
252.5 & 0 & Tap water of Abhar \\
265.2 & 10 & \\
\hline
\end{tabular}




\subsection{Conclusion}

A simple, precise and accurate method was developed for selective separation, pre-concentration and determination of copper from various complex matrices. The time taken for the separation and analysis of copper in $100 \mathrm{ml} \mathrm{sam}$ ple is at the most $20 \mathrm{~min}$. It can selectively separate $\mathrm{Cu}^{2+}$ ions from various metal ions even they are present at much higher concentrations. The method can be successfully applied to the separation and determination of copper in real samples.

\section{REFERENCES}

[1] R. Ziessel, "Schiff-Based Bipyridine Ligands. Unusual Coordination Features and Mesomorphic Behaviour," Coordination Chemistry Reviews, Vol. 216-217, 2001, pp. 195-223.

[2] P. A. Vigato and S. Tamburini, "The Challenge of Cyclic and Acyclic Schiff Bases and Related Derivatives," Coordination Chemistry Reviews, Vol. 248, No. 17-20, 2004, pp. 1717-2128. doi:10.1016/i.cct.2003.09.003

[3] C. Janiak, "Engineering Coordination Polymers towards Applications," Journal of the Chemical Society, Dalton Transactions, No. 14, 2003, pp. 2781-2804.

[4] C. M. Liu, R. G. Xiong, X. Z. You and Y. J. Liu, "Crystal Structure and Some Properties of a Novel Potent $\mathrm{Cu}_{2} \mathrm{Zn}_{2} \mathrm{SOD}$ Model Schiff Base Copper (II) Complex $[\mathrm{Cu}($ bppn $)]\left(\mathrm{ClO}_{4}\right)_{2} \cdot{ }_{2} \mathrm{H}_{2} \mathrm{O}$," Polyhedron, Vol. 15, No. 24, 1996, pp. 4565-4571. doi:10.1016/0277-5387(96)00163-5

[5] J. Szklarzewicz, A. Samotus, J. Burgess, J. Fawcett and D. R. Russell, "Structural and Spectroscopic Characterization of a Dicyanooxomolybdenum(IV) Complex with a Tetradentate Schiff-Base Ligand," Journal of the Chemical Society, Dalton Transactions, No. 18, 1995, pp. 30573061. doi:10.1039/dt9950003057

[6] S. Gourbatsis, S. P. Perlepes, I. S. Butler and N. Hadjiliadis, "Zinc(II) Complexes Derived from the di-SchiffBase Ligand $N, N^{\prime}$-Bis[1-(Pyridin-2-yl)Ethylidene] Ethane1,2-Diamine $\left(\mathrm{L}_{\mathrm{A}}\right)$ and Its Hydrolytic-cleavage Product $N$-[1-pyridin-2-yl)Ethylidene]Ethane-1,2-Diamine (L): Preparation, Characterization and Crystal Structure of the 5-Coordinate Species $\left[\mathrm{ZnLCl}_{2}\right]$," Polyhedron, Vol. 18, No. 18,1999 , pp. 2369-2375. doi:10.1016/S0277-5387(99)00141-2

[7] P. K. Bowyer, K. A. Porter, A. D. Rae, A. C. Willis and S. B. Wild, "From Helicate to Infinite Coordination Polymer: Crystal and Molecular Structures of Silver(I) Complexes of Readily Prepared di-Schiff Bases," Journal of the Chemical Society, Chemical Communications, No. 10, 1998, pp. 1153-1154.

[8] R. G. Pearson, "The HSAB Principle-More Quantitative Aspects," Inorganica Chimica Acta, Vol. 240, No. 1-2, 1995, pp. 93-98. doi:10.1016/0020-1693(95)04648-8

[9] Y. Yamini, J. Hassan and M. H. Karbasi, "Solid-Phase Extraction of Copper with Cupron on Octadecyl Silica Cartridge and Its Determination with Atomic Absorption," Microchimica Acta, Vol. 148, No. 3-4, 2004, pp. 305-309. doi:10.1007/s00604-004-0259-6

[10] P. Hashemi, S. Bagheri and M. R. Fat'hi, "Factorial Design for Optimization of Experimental Variables in Preconcentration of Copper by a Chromotropic Acid Loaded Q-Sepharose Adsorbent," Talanta, Vol. 68, No. 1, 2005, pp. 72-78. doi:10.1016/j.talanta.2005.04.058

[11] P. Ashtari, K. Wang, X. Yang, S. Huang and Y. Yamini, "Novel Separation and Preconcentration of Trace Amounts of Copper(II) in Water Samples Based on Neocuproine Modified Magnetic Microparticles," Analytica Chimica Acta, Vol. 550, No. 1-2, 2005, pp. 18-23.

doi:10.1016/j.aca.2005.06.048

[12] R. J. Cassella, O. I. B. Magalhães, M. T. Couto, E. L. S. Lima, M. A. F. S. Neves and F. M. B. Coutinho, "Synthesis and Application of a Functionalized Resin for Flow Injection/F AAS Copper Determination in Waters," Talanta, Vol. 67, No. 1, 2005, pp. 121-128. doi:10.1016/j.talanta.2005.02.019

[13] O. Acar, "Determination of Cadmium, Copper and Lead in Soils, Sediments and Sea Water Samples by ETAAS Using a $\mathrm{Sc}+\mathrm{Pd}+\mathrm{NH}_{4} \mathrm{NO}_{3}$ Chemical Modifier," Talanta, Vol. 65, No. 3, 2005, pp. 672-677. doi:10.1016/j.talanta.2004.07.035

[14] J. Y. Cabon, "Determination of $\mathrm{Cu}$ and $\mathrm{Mn}$ in Seawater by Graphite Furnace Atomic Absorption Spectrometry with the Use of Hydrofluoric Acid as a Chemical Modifier," Spectrochimica Acta Part B: Atomic Spectroscopy, Vol. 57, No. 5, 2002, pp. 939-950.

[15] P. Rumori and V. Cerdà, "Reversed Flow Injection and Sandwich Sequential Injection Methods for the Spectrophotometric Determination of Copper(II) with Cuprizone," Analytica Chimica Acta, Vol. 486, No. 2, 2003, pp. 227-235. doi:10.1016/S0003-2670(03)00493-8

[16] J. J. Pinto, C. Moreno and M. García-Vargas, "A Very Sensitive Flow System for the Direct Determination of Copper in Natural Waters Based on Spectrophotometric Detection," Talanta, Vol. 64, No. 2, 2004, pp. 562-565. doi:10.1016/j.talanta.2004.03.009

[17] S. Meseguer-Lioret, P. Campíns-Falcó, S. Cárdenas, M. Gallego and M. Valcárcel, "FI Automatic Method for the Determination of Copper(II) Based on Coproporphyrin I- $\mathrm{Cu}(\mathrm{II}) / \mathrm{TCPO} / \mathrm{H}_{2} \mathrm{O}_{2}$ Chemiluminescence Reaction for the Screening of Waters," Talanta, Vol. 64, No. 4, 2004, pp. 1030-1035. doi:10.1016/j.talanta.2004.05.004

[18] Z. Szigeti, I. Bitter, K. Toth, C. Latkoczy, D. J. Fliegel, D. Günther and E. Pretsch, "A Novel Polymeric Membrane Electrode for the Potentiometric Analysis of $\mathrm{Cu}^{2+}$ in Drinking Water," Analytica Chimica Acta, Vol. 532, No. 2, 2005, pp. 129-136. doi:10.1016/j.aca.2004.10.061

[19] M. P. Hurst and K. W. Bruland, "The Use of NafionCoated Thin Mercury Film Electrodes for the Determination of the Dissolved Copper Speciation in Estuarine Water," Analytica Chimica Acta, Vol. 546, No. 1, 2005, pp. 68-78. doi:10.1016/j.aca.2005.05.015

[20] P. Bermejo-Barrera, A. Moreda-Pineiro, R. GonzalezIglesias and A. Bermejo-Barrera, "Multivariate Optimization of Solvent Extraction with 1,1,1-Trifluoroacetylacetonates for the Determination of Total and Labile $\mathrm{Cu}$ and Fe in River Surface Water by Flame Atomic Absorp- 
tion Spectrometry," Spectrochimica Acta Part B: Atomic Spectroscopy, Vol. 57, No. 12, 2002, pp. 1951-1966.

[21] M. P. Hurst and K. W. Bruland, "The Use of NafionCoated Thin Mercury Film Electrodes for the Determination of the Dissolved Copper Speciation in Estuarine Water," Analytica Chimica Acta, Vol. 546, No. 1, 2005, pp. 68-78. doi:10.1016/j.aca.2005.05.015

[22] S. Scaccia, G. Zappa and N. Basili, "Ion Chromatographic Preconcentration of $\mathrm{Cu}$ and $\mathrm{Cd}$ from UltraHigh-Purity Water and Determination by Electrothermal Atomic Absorption Spectrometry," Journal of Chromatography A, Vol. 915, No. 1-2, 2001, pp. 167-175. doi:10.1016/S0021-9673(01)00642-2

[23] E. Kendüzler and A. R. Türker, "Atomic Absorption Spectrophotometric Determination of Trace Copper in Waters, Aluminium Foil and Tea Samples after Preconcentration with 1-Nitroso-2-Naphthol-3,6-Disulfonic Acid on Ambersorb 572," Analytica Chimica Acta, Vol. 480, No. 2, 2003, pp. 259-266. doi:10.1016/S0003-2670(03)00024-2

[24] V. A. Lemos and P. X. Baliza, "Amberlite XAD-2 Functionalized with 2-Aminothiophenol as a New Sorbent for On-Line Preconcentration of Cadmium and Copper," Talanta, Vol. 67, No. 3, 2005, pp. 564-570. doi:10.1016/j.talanta.2005.03.012

[25] U. Divrikli, A. A. Kartal, M. Soylak and L. Elci, "Preconcentration of $\mathrm{Pb}(\mathrm{II}), \mathrm{Cr}(\mathrm{III}), \mathrm{Cu}(\mathrm{II}), \mathrm{Ni}(\mathrm{II})$ and $\mathrm{Cd}(\mathrm{II})$ Ions in Environmental Samples by Membrane Filtration Prior to Their Flame Atomic Absorption Spectrometric Determinations," Journal of Hazardous Materials, Vol. 145, No. 3, 2007, pp. 459-464. doi:10.1016/j.jhazmat.2006.11.040

[26] M. Ghaedi, K. Niknam, A. Shokrollahi, E. Niknam, H. R. Rajabi and M. Soylak, "Flame Atomic Absorption Spectrometric Determination of Trace Amounts of Heavy Metal Ions after Solid Phase Extraction Using Modified Sodium Dodecyl Sulfate Coated on Alumina," Journal of Hazardous Materials, Vol. 155, No. 1-2, 2008, pp. 121127. doi:10.1016/j.jhazmat.2007.11.038

[27] A. B. Tabrizi and J. H. Mater. "Development of a Cloud Point Extraction-Spectrofluorimetric Method for Trace Copper(II) Determination in Water Samples and Parenteral Solutions," Journal of Hazardous Materials, Vol. 139, No. 2, 2007, pp. 260-264.

[28] M. Shamsipur, A. R. Ghiasvand and Y. Yamini, "SolidPhase Extraction of Ultratrace Uranium(VI) in Natural Waters Using Octadecyl Silica Membrane Disks Modified by Tri- $n$-octylphosphine Oxide and Its Spectrophotometric Determination with Dibenzoylmethane," Analytical Chemistry, Vol. 71, No. 21, 1999, pp. 4892-4897. doi:10.1021/ac981229o

[29] A. R. Khorrami, T. Hashempur, A. Mahmoudi and A. R. Karimi, "Determination of Ultra Trace Amounts of Cobalt and Nickel in Water Samples by Inductively Coupled Plasma-Optical Emission Spectrometry after Preconcentration on Modified $\mathrm{C}_{18}$-Silica Extraction Disks," Micro- chemical Journal, Vol. 84, No. 1-2, 2006, pp. 75-79. doi:10.1016/j.microc.2006.04.008

[30] A. R. Khorrami, H. Naeimi and A. R. Fakhari, "Determination of Nickel in Natural Waters by FAAS after Sorption on Octadecyl Silica Membrane Disks Modified with a Recently Synthesized Schiff's Base," Talanta, Vol. 64, No. 1, 2004, pp. 13-17. doi:10.1016/j.talanta.2003.10.057

[31] Y. Yamini, N. Alizadeh and M. Shamsipur, "Solid Phase Extraction and Determination of Ultra Trace Amounts of Mercury(II) Using Octadecyl Silica Membrane Disks Modified by Hexathia-18-Crown-6-Tetraone and Cold Vapour Atomic Absorption Spectrometry," Analytica Chimica Acta, Vol. 355, No. 1, 1997, pp. 69-73. doi:10.1016/S0003-2670(97)81613-3

[32] M. Shamsipur, A. Avanes, M. K. Rofouei, H. Sharghi, Gh. Aghapour, "Solid Phase Extraction and Determination of Ultra Trace Amounts of Copper(II) Using Octadecyl Silica Membrane Disks Modified by 11-Hydroxynaphthacene-5,12-Quinone and Flame Atomic Absorption Spectrometry," Talanta, Vol. 54, No. 5, 2001, pp. 863-869. doi:10.1016/S0039-9140(01)00336-8

[33] M. Payehghadr and R. Heidari, Conductometric studies of the thermodynamics complexation of $\mathrm{Li}^{+}, \mathrm{Na}^{+}, \mathrm{K}^{+}, \mathrm{Mg}^{2+}$ and $\mathrm{Ba}^{2+}$ Ions with $4^{\prime}, 4^{\prime \prime}\left(5^{\prime \prime}\right)$-Di-Tert-Butyldibenzo-18Crown-6 Ligand in Acetonitrile, Ethanol and Methanol Solutions," Journal of Inclusion Phenomena and Macrocyclic Chemistry, in Press.

[34] M. Payehghadr, A. Zamani, A. R. S. Sadaghiani and M. Taghdiri, "Spectrophotometric and Conductometric Studies of the Thermodynamics Complexation of $\mathrm{Zn}^{2+}, \mathrm{Ni}^{2+}$, $\mathrm{Co}^{2+}, \mathrm{Pb}^{2+}$ and $\mathrm{Cu}^{2+}$ Ions with 1,13-Bis(8-Quinolyl)-1,4, 7,10,13-Pentaoxatridecane Ligand in Acetonitrile Solution," Journal of Inclusion Phenomena and Macrocyclic Chemistry, Vol. 62, No. 3-4, 2008, pp. 255-261. doi:10.1007/s10847-008-9465-X

[35] V. A. Nicely and J. L. Dye, "General Purpose Curve Fitting Program for Class and Research Use," Journal of Chemical Education, Vol. 48, No. 7, 1971, pp. 443-447. doi:10.1021/ed048p443

[36] M. Payehghadr, M. K. Rofouei, A. Morsali and M. Shamsipur, "Structural and Solution Studies Novel Tetranuclear Silver(I) Cluster of [1,3-di(2-Methoxy)Benzene] Triazene," Inorganica Chimica Acta, Vol. 360, No. 6, 2007, pp. 1792-1798. doi:10.1016/j.ica.2006.09.015

[37] M. Shamsipur, A. R. Ghiasvand, H. Sharghi and H. Naeimi, "Solid Phase Extraction of Ultra Trace Copper(II) Using Octadecyl Silica Membrane Disks Modified by a Naphthol-Derivative Schiff's Base," Analytica Chimica Acta, Vol. 408, No. 1-2, 2000, pp. 271-277. doi:10.1016/S0003-2670(99)00873-9

[38] F. Poole, S. K. Poole, D. S. Seibert and C. M. Champman, "Determination of Kinetic and Retention Properties of Cartridge and Disk Devices for Solid-Phase Extraction," Journal of Chromatography B: Biomedical Sciences and Applications, Vol. 689, No. 1, 1997, pp. 245-259. doi:10.1016/S0378-4347(96)00282-4 